\title{
一特集 アミロイドージス
}

\section{循環器系のアミロイドージス}

栗原博*

\section{はじめに}

アミロイドージス1)は，程度の差はあって 女，多くの例で，心蔵や全身の血管系がアミロ イド物質の沈着する好発部位となるために，心 不全をはじめとする循環器系の多くの症状を呈 してくる，もちろん，同時に全身のあらゆる臓 器にアミロイドの沈着がみられるために，その 部位や程度によって，臨床症状は，きわめて多 彩となり，生前診断はむずかしい。したがっ て，高齢者で原因不明の頑固な心不全をみる時 は，常にアミロイドージスを疑ら必要があると さえいわれるくらいである。この意味で，アミ ロイドージスは, 循環器疾患としても, 特異な 注目すべき疾患の一つといえよう。ここでは， 循環器の立場からみたアミロイドージスについ て簡単にのべたい。

\section{I. 分 類}

今日をで，アミロイドージスの分類は数多く 試みられている。しかし，いずれも原因となる アミロイド物質の本態や，沈着機序について明 らかでない点が多く，成因に直接結びついた分 類は未解決とされている122).

臨床病理的には, (1)他疾患の有無により： a )原発性， b ) 続発性，(2)沈着部位の拡がりに より： a )全身性， b )局所性, (3)遺伝関係の有 無により：a )非家族性，b )家族性とに分ける のが便利であるが，いずれもこれらの間に成因 上の本質的な差があるかどうか判っていない．
続発性アミロイドージスの原因となる疾患と してはよく知られているように，結核，瀬など の慢性感染症, リウマチ様関節炎，潰瘍性大腸 炎などの慢性疾患, 悪性腫瘍, 骨髄腫, 糖尿病 などがあげられる1，骨髄腫に伴うアミロイド ージスは, 臨床的には，続発性に入れられる が，原発性と思われるものの中にも形質細胞の 増加しているものがあり，これとの関係がしば しば問題とされ，独立に扱われることも多い。

循環器系について, 特に心臓へのアミロイド の沈着には113)，全身性アミロイドージスの部

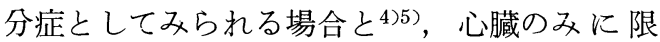
局してみられる場合とがある677).

古くから，心筋をはじめとする筋肉, 血管, 舌，皮膚など，主に間葉系組織を中心にアミ口 イドの沈着するのが基礎疾患のない原発性アミ ロイドージスの特徵とされ，一方続発性のもの では, 肝, 腎, 脾といった実質臓器の毛細血 管, 腺周囲性にアミロイドの沈着がみられ，心 臓への沈着の頻度は少ないといわれていた。し かし，今日，中川ら8) の統計をみてもこれらの 原則はあてはまらないことが知られてきてい る。すなわち，原発性にせよ，続発性にせよ， 全身性にみられる場合には，程度の差はあって も，心・血管系にアミロイドの沈着がタられる といえる。

一方，局所性アミロイドージスの中には，心 臓のみに限局して, 特異的にアミロイドのみら れるものがある。もちろんよくしらべると，他 の臟器にもアミロイドの沈着が多少ともみられ ることもあるが，心蔵が主体で，原発性に老人 に多くみられるので，特に老人性心アミロイド

* 東京大学医学部第三内科 
表 1 原発性アミロイドージスの 年代別本邦報告例

\begin{tabular}{c|c|c}
\hline 年 代 & 症 例 数 & 生検診断数 \\
\hline$\sim 1945$ & 1 & 0 \\
$1946 \sim 1950$ & 1 & 0 \\
$1951 \sim 1955$ & 5 & 1 \\
$1956 \sim 1960$ & 12 & 4 \\
$1961 \sim 1965$ & 50 & 15 \\
$1966 \sim 1970$ & $41\left(+55^{*}\right)$ & 19 \\
\hline 計 & 110 & 39 \\
\hline
\end{tabular}

（*家族性アミロイドージス 5 家系55例）

ージス (senile cardiac amyloidosis) として取り 扱われている9 .

さらに, 家族性に発生する種々の型のアミロ イドージスがあり, 本邦でもすでに 5 家系報告 されている10) 15)。神経系統が主に侵される家 系が多いが，この中には，心臓も部分症として 侵される場合も少なくない。特に原発性に, 心 臓が主に侵された例としては, Fredriksen ${ }^{16)}$ や Coelho17）らの報告した家系がある。

\section{II. 頻度}

もともと，アミロイドージスは，本邦ではき わめて稀な疾患とされていたが, 最近, 急速に 症例が増してきているようである。このこと は, 本年度の第69回日本内科学会総会シンポジ ウムで「本邦人のアミロイドージス」がとりあ げら゙れ，この中での各演者の報告でも明らかで ある18). 著者ら ${ }^{19)}$ も1963年に, 老年者の原発性 心アミロイドージスの 1 例を経験した際に, 本 邦での原発性アミロイドージスの報告例をまと めた時には, 1943年の太田の第 1 例以後, 26例 しか見当らなかったが，最近もら一度しらべて みると（表 1)，1970年までにさらに 84 例が加 わり, その他, 最近知られた家族性了ミロイド ージスの 5 家系内の疑いをも含めた約 55 例を加 えるとすでに 165 例に及ぶ症例があることにな る.この他, 原発性よりもさらに多いとみられ る続発性のものを加えると, アミロイドージス は，もはや本邦でもそれほど稀な疾患とはいえ ないよらに思われる。しかも，近年生検技術の 普及とともに，生前に診断できた原発性アミロ
イドージスの症例はすでに 39 例報告されてい る.

一方, 剖検数に対するアミロイドージスの頻 度も年々増加し, 中川によると年), 最近では 1.73\%に至って扣り，次第に欧米のそれに近く なってきているといわれる。

また前にあげた文献上の本邦の原発性非家族 性アミロイドージスの 110 例中, 剖検された 94 例のらち，89例 $(94 \%)$ に心臓へのアミロイド の沈着が記載されている。

\section{III. 病 理 ${ }^{4) \sim 7(20) 21) 27) ~}$}

すでに心アミロイドの病理については, 多く の記載がある。もちろん, アミロイドの沈着の 程度により一定しないが，心蔵は硬くなり，壁 は厚く, 弾力性が失われ，心重量は增加する。 本邦の原発性剖検例34例の心重量は $135 \mathrm{~g}$ から $750 \mathrm{~g}$ で, 平均 $437 \mathrm{~g}$ であった. アミロイドの沈 着は心蔵の各層にみられ, 中でも心筋層に著明 である。その様式も，びまん性あるいは小結節 状で一定しない，肉眼的に，心内膜に小結節状 に隆起するものや，心筋層が全体にアミロイド で占められるものまである。また，冠動脈壁に 沈着するもの，心外膜の表面に小結節を形成す るもの，あるいはは心外膜が肥厚する場合もみ られる。

組織学的には，アミロイド物質は，心筋線維 をとりかこんで，間質に沈着し，心筋線維は萎 縮し，壊死を扣こしてくるが，炎症性変化はみ られない、アミロイド物質は, 組織学的には thioflavin- $\mathrm{T}$ 螢光法, あるいは Congo-red, crystal violet や methyl violet による metachromasia の性質, 偏光顕微鏡によるアミロイド 線維の複屈折の性質などで証明される1). さら に電子顕微鏡で, アミロイドの線維性構成をみ ることができる21).

心筋内の部位では, 心房, 心室, 乳頭筋, あ るいは冠動脈壁, 毛細血管の周囲, その他, 洞 結節，房室結節，刺激伝導など，あらゆる部位 に沈着がみられる。伝導系の中では, 洞結節が 侵され易いといわれる20). その原因として，洞 結節組織が periarterial の組織と似ているため 
とも考学られている。 心内膜へのアミロイドの 沈着は, 弁や腱索に及べば, 弁膜は硬くなり, 心雑音の原因となる。時には, 冠動脈壁への沈 着から,これが閉塞されると, 冠動脈硬化性の 心筋虚血性変化と同様に, 心筋の線維化を扣こ すこともある。

その他, 心蔵以外では, すでにのべたょら に, 全身性に, あらゆる臟器の血管系を中心と して, すなわち, 動脈壁, 静脈壁, 毛細血管周 辺にアミロイドが沈着すると, それぞれの臓器 の細胞は萎縮や壞死を抏こし, その臓器特有の 症状を示すことになる．たとえば消化管の血管 への沈着は, 下痢, 下血やイレウスの原因とも なる。

\section{IV. 性 ・ 年 齢}

本邦での原発性非家族性アミロイドージスの 報告例の性・年齢は表 2 亿示した。 やや男性に 多く, その年㱓は18歳から92歳に及んでいる. これに比へ，家族性のものは，比較的若年者に 発症するものが多い13). Pomerance ${ }^{9)}$ によると 老人性心アミロイドージスは70歳以下では泣と んどみられず， 70 歳以上で $12.5 \%$ みられ， 年齢とともに増加する。すなわち 80 歳以上では $23 \% ， 90$ 歳以上で50\%に及ぶという。

\section{V. 臨床症 状(1)27)}

心不全は, 原発性アミロイドージスの主要な 初発症状であり, 動悸, 息切れ, 頻脈, 浮腫な ぞによって始まることが多い，もちろん，他の 臓器へのアミロイドの沈着による症状として, 肝腫, 脾腫, 蛋白尿, 甲状腺腫, 下痢, 下血な ぞがみられることも少なくない。

しかしながら, 進行性の心不全は, 心藏にア ミロイドの沈着する場合には，きわめて特徵的 で, 頑固で, 治療に抵抗する。疾患の症状 は，一般には $50 \%$ 以上にみ.られるとされるが,

Cohen ${ }^{11}$ によると，原発性では $80 \%$ に，骨髄腫 を伴うものに $90 \%$ に，また続発性のもので $60 \%$ の高率にみられたといら。公不全としては，ア ミロイドの沈着の範囲にもよるが，右心不全， 左心不全がともにおこり，また肺血管系にアミ
表 2 原発性非家族性アミロイドージス本邦報 告例の性・年跉別頻度（1943～1970）

\begin{tabular}{c|r|r|r}
\hline 年龄(歳) & 男 & 女 & 計 \\
\hline$\sim 20$ & 0 & 3 & 3 \\
$21 \sim 30$ & 2 & 1 & 3 \\
$31 \sim 40$ & 6 & 1 & 7 \\
$41 \sim 50$ & 15 & 4 & 19 \\
$51 \sim 60$ & 24 & 18 & 42 \\
$61 \sim 70$ & 16 & 11 & 27 \\
$71 \sim$ & 5 & 4 & 9 \\
\hline 計 & 68 & 42 & 110 \\
\hline
\end{tabular}

ロイドの沈着があれば，肺性心の状態となる。 体動時の息切れ, 夜間の発作性呼吸困難, 浮腫 などが目立ってくる。

\section{VI. 血 行 動 態16)22}

心筋内にアミロイドが沈着することにより， 心筋の弾力性は低下し. 本来の心筋の収縮や拡 張が阻げられて, その血行動態は, 収縮性心膜 炎 (constrictive pericarditis) にみるのと非常に よく似た状態となる ${ }^{22)}$.このため, 心拍出量の 低下, 一回駆血量の低下, 脈圧の減少, 静脈圧 の上昇, 末梢の浮腫となって現われる.

右心カテーテルの行なわれた症例は本邦では 見当らないが，Gunnar ${ }^{22), ~ F r e d e r i k s e n ~}{ }^{16)}$ らの 例をみると，アミロイドは一般に左右の心室の 心筋に沈着するために, 肺動脈揳入圧および右 房圧はともに上昇し, 左右両心室の拡張終期圧 の上昇を示している。一方, 圧カーブの上から は, 右房圧曲線は, 平均圧の上昇とともにいわ ゆるM型またはW型を示す。すなわち, 心室収 縮期に全体として丸味を帯びて上昇し，ついで 急激な $\mathrm{y}$ 波の下降をみるのを特徵とする. 右室 内圧カーブは, 静脈圧の上昇と心室の拡張不全 により，急速に心室に血液充満がおこるため に, いわゆる dip and plateau の形を示す。す なわち，拡張早期に圧の陥凹 dip をきたし，そ れにつづいてすぐに, 拡張期圧は高く上昇し, 平坦に高い拡張終期圧につながる形を示すのが 特徵とされる。一方収縮期圧は, 高い拡張終期 圧にもかかわらずあまり上昇しない。したがっ 


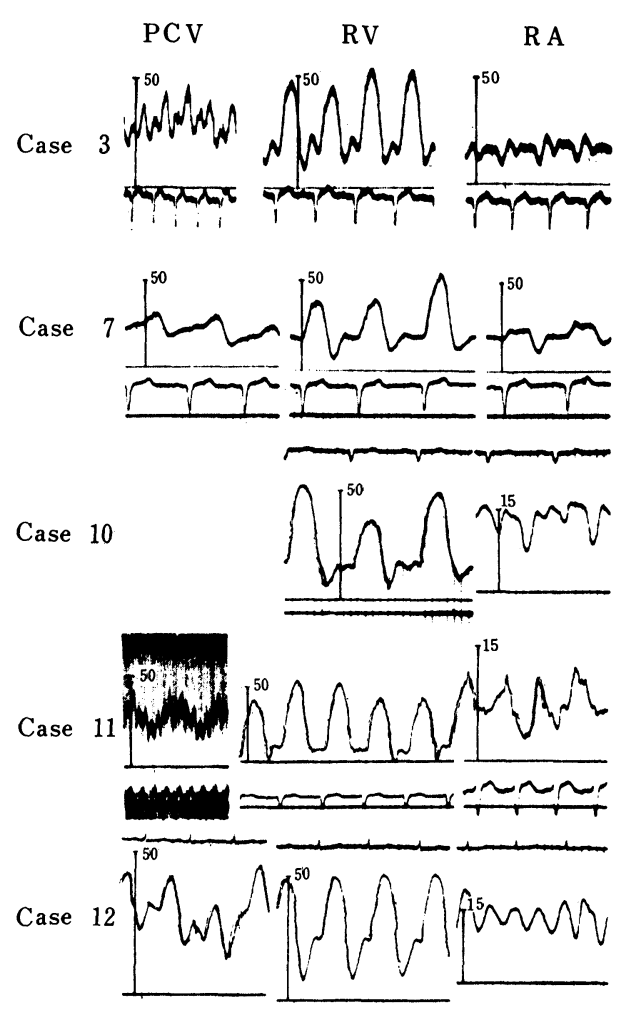

図 1 右心カテーテル圧カーブ $\mathrm{PCV}$ : 肺動脈揳入圧, $\mathrm{RV}$ ：右室圧, RA：右房圧

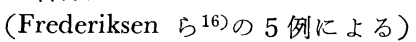

て，拡張終期圧の収縮期圧との比は，容易に $1 / 3$ 以上となる。しかしながら，このような所見 は, 心アミロイドージスだけの特有な所見では なく, 心臟の筋層や内外の心膜の病変によっ て, 心室が拡張期に血液の充満を妨げられた時 に常にみられる所見である23)。中でも，収縮性 心膜炎，あるいは，原因不明の心筋心内膜疾 患, たと六ば心内膜線維弾性症や心筋線維症な どに共通する所見である。

心拍出量の低下は, 運動負荷でも増加しにく い。地動脈圧は低下し，同時に矢の波形も 収縮期の peak は細い形となる。心アミロイド の沈着の具合によって, 左室の流出路に狭窄を 拈こし, 特発性筋肥大性大動脈弁下部狭窄症と きわめて類似した例の報告もみられる24).
表 3 心アミロイドージスの心電図所見 (31例について)

\begin{tabular}{ccc}
\hline 低 電 位 差 & 25 例 & $80.0 \%$ \\
$\mathrm{~V}_{1}-\mathrm{V}_{3} \mathrm{QS}$ 型 & 16 & 52.0 \\
第 1 度房室ブロック & 11 & 34.3 \\
心室性期外収縮 & 10 & 32.0 \\
異 常 $\mathrm{T}$ 波 & 10 & 32.0 \\
心 房 細 動 & 9 & 29.0 \\
左脚 ブロッ ク & 3 & 9.6 \\
右脚 ブ ック & 2 & 6.4 \\
心 筋 硬 塞 & 2 & 6.4 \\
左 軸 偏 位 & 19 & $61.6 \%$ \\
平均 心 重 量 & & $463.4 \mathrm{~g}$ \\
正 常 電 気 軸 & 7 & $22.5 \%$ \\
平均心 重 量 & & $290.0 \mathrm{~g}$ \\
右 軸 偏 位 & 5 & $16.6 \%$ \\
平均心 重 量 & & $469.2 \mathrm{~g}$ \\
\hline
\end{tabular}

(Eliot, R. S., et al. による) ${ }^{25)}$

\section{VII.心 電 図 ${ }^{25) 26) 27)}$}

原発性アミロイドージスの心電図についても すでに Eliot ${ }^{25)}$ (表 3) をはじめ多くの統計が

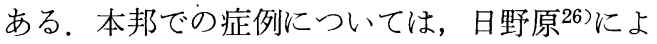
る最近の統計によると, 頻度は, Eliot ${ }^{25)}$ Bu ja ${ }^{27)}$ らの報告の 頻度ときわめて近い数字が あげられている、いずれもアミロイドージスの みに共通した特異的な所見といえるものはな い。しかし，しばしばみられるものとしては, 低電位差, $\mathrm{V}_{1}-\mathrm{V}_{3}$ の QS 型, 左軸偏位, 伝導障 害, 脚ブロック, 種々の形の不整脈 (心房細 動，期外収縮その他）などがあげられる。こう した所見を原因の不明な心不全の高秢者にみた 場合には，いつも心アミロイドージスを疑ら価 值は充分にある。図 2 は自験例 ${ }^{19}$ の心電図を示 寸.

低電位差は，もちろん心アミロイドによるば かりでなく, 全身の浮腫なども関係するが, 普 通もっともよくみられるもので，日野原は， 77. $4 \%$ の数字をあげている26). $\mathrm{V}_{1}-\mathrm{V}_{3}$ の QS 型 も半数近くにみられるとされるが, 冠動脈硬化 症による心筋硬塞とまぎらわしい、はっきりと した硬塞発作なしに徐々に変化が進行する。一 方, 電気軸の变化もしばしばみられ, Eliot ${ }^{25)}$ 
によれば,これらの左軸偏位や，右軸偏位を示 した症例の心重量は重いとされている.

不整脈もよくみられる所見の一つである。そ の原因として，アミロイド物質が，直接心筋や 刺激伝導系組織に沈着することによることはも ちろんであるが20)，その他冠動脈壁への沈着に よる心筋や伝導系組織の二次的虚血，あるいは 自律神経節へのアミロイドの沈着による神経性 因子, 他の臓器への沈着により括こされる全身 性代謝性因子，例えば，尿毒症，肝性昏睡，心 不全に伴ら電解質の变化, さらにはジキタリス や利尿剂などの薬物などが関係する。

不整脈の形としては, 心蔵の刺激生成の異常 として, 洞性頻脈, 心房細粗動, 結節調律, 発 作性上室性頻拍，上室性ない儿心室性期外収 縮などはしばしばみられる。一方刺激伝導の異 常として，房室伝導障害には単なる $P Q$ 延長 から高度の房室ブロックに至るものまであり, Adams-Stokes 発作 28$)$ 女稀ではなく, 本邦例で も 4 例の報告があり，急死の原因となり得る.

病理学的にもすでにふれたように, 洞結節は アミロイドの沈着の好発部位であり ${ }^{20)}$, 心房細 動をキニジンや DC ショックを用いても，洞調 律に戻りにくいとされている。

\section{VIII.レントゲン所見}

心陰影は中等度に拡大し, 透視上, 心藏の動 きは少ないとされるが，特に心アミロイドージ スに特有な所見はない, 胸水の貯留も, 心不全 に伴ってみとめられる。

\section{IX. その他の症候}

血圧はアミロイドージスの進行とともに低く なることが多い，原因として，先にあげた一回 駆出量や心拍出量の低下，心収縮力の低下など とともに，副腎の機能不全や，末梢血管へのア ミロイド沈着による末梢抵抗の減少などが考え られている。起立性低血圧は，特に神経症状を 主徵とするアミロイドージスではよくみられる もので13)，自律神経障害が関係するものとみら れる。

失神発作は，心アミロイドージスの約 $25 \%$ に
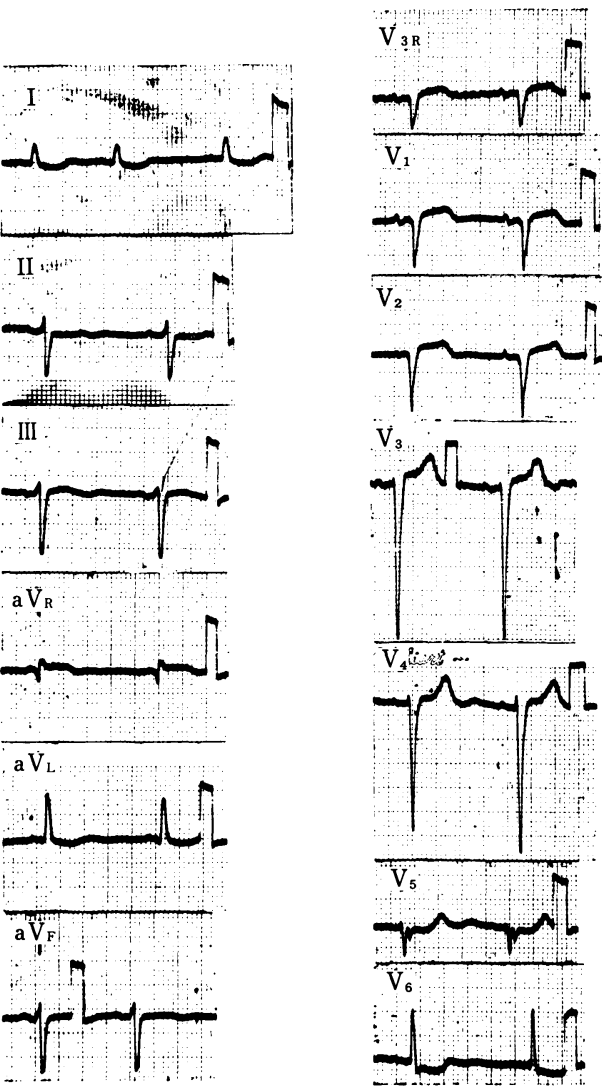

図 2 自験例 ${ }^{19)}: 92$ 歳 ( 9 ) の原発性心〉ミ イドージスの心電㘡. (死亡 2 力月前) 電穸軸は一60度的強い左軸偏位を示し， $\mathrm{V}_{3 \mathrm{R}} \sim \mathrm{V}_{2}$ は $\mathrm{QS}$ 型, $\mathrm{V}_{3} \sim \mathrm{V}_{5}$ の $\mathrm{R}$ は小 さく $V_{5}$ で深い $\mathrm{S}$ を示す. ST.Tはジ タリスの影響で低下がみられる。全体と して低電位はみられていない。

おこるといわれる20)．急におこった洞機能の抑 制，あるいは房室ブロックにひきつついて，下 位での補充調律の欠除する場合，または種々の 不整脈による心拍出量の急激な低下，心臓より 発する迷走神経への反射などがその原因として あげられる。

\section{X. 循環器系以外の症候}

全身性アミロイドージスでは, 心臓以外の臓 器のアミロイドの沈着による種々の症状は, 診 断上重要である。巨大舌, 皮下出血, 皮膚や粘 膜のアミロイド結節, ネフローゼ症候, 肝・脾 腫, 甲状腺腫, 唾液腺腫, 下痢, 下血, 喉頭 
ミロイド結節による嗄声，末梢神経障害などが あげられる。

\section{XI. 診 断}

局所性心アミロイドージスは, 直接臨床的に 診断されることはまず少ない，らっ血性心不全 を主徵として, 広義の原発性心筋疾患 (primary myocardial disease) として取り扱わざるを得な いことが多い.

全身性アミロイドージスの部分症としての心 アミロイドージスでは, 心不全とともに，先に あげた心以外の各臓器の症候を参考とする。 ず本症の存在を疑うことが出発となる。

臨床検査上にも，特異的な検査所見はなく, Congo-red 試験も古くから行なわれているが, アミロイドの沈着の分布や程度により影響をう け，信頼できる検査といいにくい1).

したがって, 直接の証明は, 今日, 組織の生 検以外に確実な方法はない。少しでもアミロイ ドージスの疑いのある場合には，積極的に組織 生検を行ならべきである。しかし，アミロイド 組織はしばしば出血傾向が強いので, 危険度の 少ない直視下で可能の部分から行ならべきであ り，この目的のためには，直腸粘膜，皮膚，歯 缺民, 上気道, 胃粘膜, 甲状腺, リンパ腺, 筋肉, 末梢神経，骨髄などがあげられる，肝・腎の生 検も診断上きわめて有力であるが，出血に対す る注意が特に必要である。 Blum らの報告によ る297藏器別の生検診断率は表 4 のようである が，安全性や容易性から，直腸生検の利点をあ げている。

\section{XII. 鑑別診断}

心アミロイドージスの鑑別疾患として，(1)収 縮性心膜炎, (2)冠動脈硬化性心疾患, (3)後天性 心弁膜症, (4)原発性心筋疾患のすべてがあげら れる．特に収縮性心膜炎とは区別しにくく，時 には，開胸手術の行なわれた例もある16). 結局 は, 他の組織でのアミロイドを生検で証明する ことが必要である。
表 4 アミロイドージス症例の臓器別生檢陽性率

\begin{tabular}{|c|c|c|c|c|c|}
\hline 蔵 & 器 & 計 & 陽 性 & 陰 性 & 陽性率\% \\
\hline 腎 & 臓 & 24 & 21 & 3 & 87.5 \\
\hline 直 & 腸 & 62 & 47 & 15 & 75 \\
\hline 肝 & 臓 & 27 & 13 & 14 & 48 \\
\hline 歯 & 㓻 & 32 & 6 & 26 & 19 \\
\hline
\end{tabular}

\section{XIII. 予後・治療}

進行性の心不全をおこし, 予後はきわめて不 良で, 経過は通例 2 年以内で死亡する ${ }^{3}$. 。不 全の対策と, 絶対安静とにより，一時的には効 果はあっても, 次第に治療に抵抗し，ジギタリ ス中毒をおこし易くなる，らっ血性心不全，尿 毒症, 胃腸管出血, 脾破裂, 急性心死, イレウ ス，上腸間膜動脈血栓などが死因にあげられて いる，治療としては，心不全の対策以外に決定 的な治療法は知られていない。

おわりに

以上循環器の面よりみたアミロイドージスの 一端を概説した。 心アミロイドージスの症例 は, 老年人口の増加とともに，これからますま す増加してくるものと推定され，他の疾患との 鑑別上，次第に重要な疾患となってくるものと 思う. 今後その生化学的に病因が解明されて, 治療上の何らかの糸口でも見つけられることを 期待せざるを得ない。

（最後に小坂教授，池田助教授の御校閲を感謝する）

\section{文献}

1) Cohen, A.S.: New Engl. J. Med., 277; 522 530, 574 583, 628 639, 1967.

2）高月 清：最新医学， 24；845 851， 1969.

3) Brigden, W.: Progr. Cardiovasc. Dis., 7; 142 $\sim 150,1964$.

4) Jones, R.S. and Frazier, D.B.: Arch, Path., 50; 366 384, 1950.

5) Jackson, A. and Slavin, M.: Am. Heart J., 47; 839 844, 1964.

6) Josselson, A.J., Pruitt, R.D. and Edwards, J.E.: Arch. Path., 54; 359 367, 1952.

7) Thomashow, A. I., Angle, W.D., and Mor- 
rione, T.G.: Am. Heart J., 46; 895 905, 1953.

8）中川定明, 小堀廸夫, 佐藤公康：日内会誌, 54; 1297 1302, 1966.

9) Pomerance, A.: J. Path. \& Bact., 91; 357 367, 1966.

10）中尾喜久, 東儀英夫, 古川哲夫, 他：臨床神経 学, 6; 369, 1966.

11）荒木淑郎, 馬渡志郎, 大田典也, 他：脳と神経, 20；11 18, 1968.

12）松本英世, 奥薗裕二, 吉田憲史, 他：内科, 23；955～962，1969. (11と同一家系)

13）山崎 昭, 吉沢 攻, 島野毅八郎, 他: 日内会 誌, 58; 499 505, 1969.

14）井沢 清, 鈴木正博, 本間義章, 他：臨床神経 学, 9; 292, 1969.

15）小鶴三男, 楢本純一, 武富弘行, 他：胃々腸, 5; 381 386, 1970.

16) Frederiksen, T., G $\phi$ tzsche, H., Harboe, N., et al.: Am. J. Med., 33; 328 348, 1962.

17) Coelho, E., and Pimentel, J.C.: Am. J. Cardiol., 8; 624 632, 1961.

18）第69回日本内科学会総会シンポジゥム（司会） 中尾喜久, (演者): 荒木淑郎, 高橋忠雄, 日野 原重明，螺良英郎，中川定明：日内会誌, 60；
（臨時增刊号）31 33，1971.，日内会誌，61； $744 \sim 779,1972$.

19）栗原 博, 寺沢富士夫, 関增爾, 他：老年病, 8; 339 344, 1964.

20) James, T. N.: Ann. Int. Med., 65; $28 \sim 36$, 1966.

21) Husband, E.M. and Lannigan, R.: Brit. Heart J., 30; 265 268, 1968.

22) Gunnar, R.M., Dillon, R.F., Wallyn, R.J., et al.: Circulation, 12; 827 832, 1955.

23) Yu, P.N., Cohen, J., Schreiner, B.F.J., et al.: Progr. Cardiovasc. Dis., 7; 125 141, 1964.

24）林 明德, 磯清隆, 栗山源秡, 他：日循誌, 31；361， 1967.

25) Eliot, R.S., McGee, H.J., and Blount, S.G. Jr.: Circulation, 23; 613 622, 1961.

26）日野原重明：日内会誌, 61；745～749，1972.

27) Buja, L.M., Khoi, N.B., and Roberts, W.C.: Am. J. Cardiol, 26; 394 405, 1970.

28) Brownstein, M.H.: New York J. Med., 66; 397 399, 1966.

29) Blum, A., and Solar, E.: Lancet, 1; 721 724, 1962.

\section{Hippocrates books}

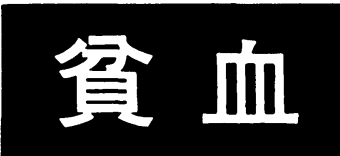

東邦大学名誉教授

森田久男著
血液研究40年の著者が語る貧血のすべて!! 一主要目次一

貧血とは・貧血の原因・貧血の分類・急性の出血・低色性筫血・鉄欠乏性 質血に特徵的な症状・日本人の筫血傾向・インドネシア・妊婦の筫血・悪

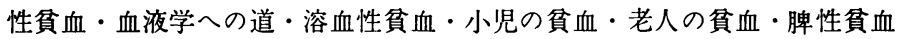

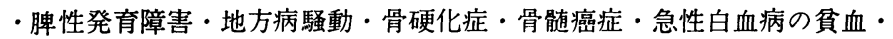
純粋な再生不能生負血・再生不能性督血

新書判 200頁 定 価1,000円（干80）東京医学社刊 